\title{
Examining The Plays That Preschool Children Prefer and The Characteristics Shaping Them Using Draw and Tell Technique
}

\author{
Dondu Neslihan Bay, PhD \\ Eskisehir Osmangazi University, Turkey
}

Doi:10.19044/ejes.v7no2a7 URL:http://dx.doi.org/10.19044/ejes.v7no2a7

\begin{abstract}
In this study, the play preferences of 80 five-year-old children, 40 girls and 40 boys, from four schools in Turkey and the characteristics that shape their preferred plays were examined. The research was designed by descriptive method, which is one of the qualitative research patterns, and the data were collected using draw-and-tell technique. Crayons and drawing papers were distributed to the children participating in the study and they were asked to draw a play they wanted to play. During the drawing, the children were interviewed by asking questions. Thematic analysis method was used in the study; open coding was performed to group the drawings and interview records of the children under the themes and sub-themes. As a result of thematic analysis, five main themes were created regarding the plays preferred by children and how and where they prefer to play them. The results showed that all children preferred open-ended plays, they mostly prefer modern plays (50\%) (type of play), playing with friends (44\%) (social connection), dynamic plays (69\%) (physical function), indoors plays (54\%) (playground) and to use ready-made toys (42\%) (toys used).
\end{abstract}

Keywords: Children, play, toys, physical function, social connection.

\section{Introduction}

Pre-school education, which is free-of-charge and optional in state schools, is considered to be very important in Turkey. It is aimed to gradually include pre-school education within the scope of compulsory education, to support all children by increasing the quality of education services and to establish common quality standards (Ertuğrul, 2019; MoNE, 2018). Analyzing the interests and needs of pre-school children in Turkey will provide pedagogical support to teachers. 
In preschool period, children show a rapid growth and development, and the basis of their learning experiences is formed. Interventions in this period, to be made through education can create permanent effects on the child's cognitive capacity, social behavior and personality (Bredekamp, 2015). Therefore, to support the development of the children, teachers should prepare qualified programs considering their individual differences, and provide children with various activities (Wortham, 2006). In providing children with the necessary support, one of the most effective learning ways is play, in which children willingly take part and have fun (Abacı \& Çıtak, 2017). Allowing children to play and providing them with positive and pleasurable learning environments are among the objectives of preschool education (Fisher, HirshPasek, Golinkoff, Singer, \& Berk, 2011). In this study, the preferences of 80 children, attending preschool education in four schools in Turkey and the characteristics that shape their preferred plays were examined using draw-andtell technique. As far as is known, no research targeting this cultural structure has been conducted before, by using draw-and-tell technique.

\section{The Significance of "Plays Preferred by Children and the Characteristics of these Plays" Study}

There are some reasons that were considered important in the planning

of this research involving the plays preferred by children and the characteristics of these plays. One of the most important reasons is that play was found to be of fundamental importance for the learning and development of children (Gialamas, Mittinty, Sawyer, Zubrick, \& Lynch, 2014; Özdenk, 2007; Pellegrini, 2011; Pinto, Pessanha, \& Aguiar, 2013 Türkmenoğlu, 2005). Plays is a key element for the development that requires learning (Smith \& Hart, 2004). Therefore, the play is used as a method facilitating the development and learning of children and play activities are planned accordingly (Theobald et al., 2015). The play, which allows to learn many concepts and skills, can also be a guide for teachers in the preparation of educational programs as an activity, in which children show their own traits (Saracho, 2012). Teachers are expected to observe children's play preferences in order to provide a qualified education that provide children with the opportunity to learn and develop (Koçyiğit, Tuğluk, \& Kök, 2007).

The second important reason is the concept of child participation developed by Laevers (2003). Participation indicates a process in which the child exists as a learner. Observable qualities of the children participating in the learning process come in view, which provides the teacher with information about possible interventions in the participation process. These two emerging factors can be considered as important indicators in terms of assessing the quality and efficiency of the educational process (see Miranda, Larrea, Muela, \& Barandiaran 2017). Participation of children in play 
activities is possible with the practices in which they are encouraged to play games that they like and enjoy. Unlike adults, children, who feel happy when they participate in an activity they love, have their own sense of entertaining play, (Howard \& McInnes, 2013). In order to ensure and increase the participation of children in play activities, children should express the play that they enjoy, and these plays should be understood by the teachers.

In addition, since the preschool education environment allows interaction with peers in plays, it creates social contexts and provides an opportunity to examine the plays in the social context (Coplan, Rubin, \& Findlay, 2006). Play often tends to take place among children (Goncu \& Weber, 2000) and it is perceived as a play by the children only when it is played with their peers (Robson, 1993). The social plays that children play with their peers allow the use of cognitive and communicative skills in the process of self-expression and understanding the other party (Howes, 2011). During the plays that children define as activities without teachers (Robson, 1993; Howard, Jenvey, \& Hill, 2006), the instructions given by teachers may cause a decrease in children's playing behavior (Wilcox-Herzog \& Kontos, 1998). Therefore, play activities should not be planned as activities that look like games from an adult's perspective, but activities that adopt an entertaining approach in which the knowledge gained about the child's sense and understanding of play are used (Howard et al., 2006).

It is thought that there are limited number of studies about children's play preferences and the characteristics of these plays in Turkey, and that these studies do not adequately represent the thoughts of children in preschool period. It has been observed that the studies were mostly conducted to determine the contribution of the play to the development of the child (Erbay \& Durmuşoğlu Saltal1, 2012; Koçyiğit, Tuğluk, \& Kök, 2007; Mangır \& Aktaş, 1993; Ulutaş, 2011); the studies that involve identifying children's play preferences were based on teacher opinions (Kaçar, 2016; Özdemir \& Ramazan, 2014) and observing children (Özdemir, 2014; Taş, 2018; Uygun \& Kozikoğlu, 2019); children were asked to show the play they prefer among the offered choices (Sapsağlam, 2018); some studies attempted to identify the plays by asking to draw the toy (Aksoy \& Baran, 2017); and interviews were conducted with children (Koçyiğit \& Baydilek, 2015; Tuğrul, Aslan, Ertürk, \& Altınkaynak, 2014). This study used draw-and tell technique for identifying the play preferences and the characteristics of the plays in the context of Turkey. This technique, which allows children to present their perspective by using drawing and explanation together, enriches the interpretation of the collected data (Cammisa, Montrone, \& Caroli, 2011). To contribute to the existing literature, we attempted to analyze children's plays in a new cultural context: namely Turkey. 


\section{The Characteristics that Shape Children's Plays}

Children perceive the activities preferred by themselves, free of adult control and intervention, as plays (Howard et al., 2006; Wong, Wang, \& Cheng, 2011). Therefore, according to the children, for an activity to be a play it should include entertainment, toys, preference right and action (Koçyiğit \& Baydilek, 2015). Therefore, the play is a free activity in which children act freely according to their own wishes (Sun \& Seyrek, 1997). In free activities, which are called unstructured, children determine the play they want, as well as the time, the way and the people they want to play with. Free plays are very important in their social, cognitive and creativity development (Santer, Griffiths, \& Goodall, 2007; Tuğrul, Boz, Uludă̆, Aslan, Çelik, \& Çapan, 2019).

Children tend to play socially and communicating with their peer during this period (Coplan, Rubin, \& Findlay, 2006). Social participation of the children in the plays is classified as solo, parallel and group (Parten, 1932). Children go through social interaction stages by beginning with parallel play. Group plays played with peers are seen as plays that allow social participation by providing the highest level of social interaction (Howard et al, 2006; Miranda et al., 2017).

In addition, children prefer to play freely the plays that they enjoy, in an imaginary way and in open spaces (Nicholson, Kurnik, Jevgjovikj, \& Ufoegbune, 2011). Regarding the plays that children play in open spaces, the behavior of playing with natural toys obtained from nature also come to the fore (Aslan, 2010; Tuğrul et al., 2019). However, in some studies, it was found that children are moving towards stationary and individual indoors plays that are not dynamic (Akçay \& Özcebe, 2012; Alabay \& Güder, 2018; Gündoğdu, Seytepe, Pelit, Doğru, Güner, Arıkı, Akçomak, Kale, Moran, Aydoğdu, \& Kaya , 2016; Koçyiğit \& Baydilek, 2015; Sapsağlam, 2018). Factors such as increased insecurity towards the environment with the changing social life and rapid development of technology cause children to turn to indoor virtual games played in computers and tablets (Frrat, 2013). But, playing in natural areas stimulates children's curiosity, environmental awareness, and supports the development of speaking and listening skills (Waite, 2010).

\section{Theoretical Framework}

Studies on children's plays are important in terms of cognitive (Piaget, 1962) and social constructivism (Vygotsky, 1978) development theories. Piaget (1962) stated that children structure the knowledge in themselves; he emphasized that the play allows to understand the feelings and thoughts of peers by interacting with other children and supports children's social and emotional development. 
In addition to gaining skills such as sharing, conflict resolution, and self-defense by interacting with their playmates, children who play develop a sense of resilience to future challenges (Pellegrini \& Smith, 1998). According to Vygotsky's (1978) social constructivism theory, play is a natural learning tool that enables children to reach their potential levels as a result of interacting with each other. Play is the most natural learning environment where children repeat, reinforce and try what they see and hear (Yavuzer, 2000). In Vygotsky theory, he emphasizes the importance of the play in learning and recommends that educators present the opportunity for every child's development and learning with play experiences (Taylor and Boyer, 2020). The opportunity to play, which is a way of learning life in preschool period, should be given to children and the content of education should be enriched with plays (Emslie and Mesle, 2009) because children increase their conceptual abilities, world knowledge and abstract thinking through the play (Taylor and Boyer, 2020). Studies have shown that the play facilitates learning by enabling children to develop and increase their knowledge and skills as a result of interacting with others and the environment (e.g., Ashiabi, 2007; Han, Moore, Vukelich, \& Buell, 2010; Weisberg, Zosh, Hirsh-Pasek, \& Golinkoff, 2013). Therefore, these theoretical perspectives emphasize that the play that enables children to develop and learn by social interaction is very important.

\section{Purpose of the Current Study}

There may be differences between the play preferences and play characteristics of children from different cultures (Duman \& Temel, 2011). The purpose of this study is to examine children preferred plays and the characteristics shaping these plays using draw-and-tell technique in four preschool classes in Turkey. In the current study, children were asked to draw the plays they prefer, and questions were asked about their drawings.

The following research question and two sub-questions were addressed:

- What are the plays preferred by Preschool Children and what are the characteristics that shape these plays?

- What are the play preferences of preschool children?

- What are the characteristics that shape the plays of preschool children (playground, material, players)?

\section{Methodology}

In this study, a descriptive research based on qualitative analysis was conducted to reveal the plays that children prefer. "Draw-and-tell" technique was used within the scope of the descriptive research. The draw-and-tell technique is a method that reveals the perceptions and experiences of children by minimizing the impact of the researcher and it is very suitable for a research conducted with children with its inclusiveness (Angell, Alexander, \& Hunt, 
2015). Children can generate their feelings and thoughts, which can be complex or abstract, by drawing (Horstman, Aldiss, and Richardson, 2008). Therefore, draw-and-tell technique is a child-centered method that supports children's thinking processes and enables the communication with children (Morrow \& Richards, 1996).

\section{Participants}

80 five-year-old children, 40 girls and 40 boys, from a total of four schools (two kindergartens and two nursery classes of primary school), have participated in the study. Homogeneous sampling, from purposive sampling methods (Patton, 2014), was used to determine the participants. All children participating in the research were children with no special needs and normal development. Schools have medium sized playgrounds for children, which are comprised of wood, grass and concrete ground. There is also equipment such as swings and slides in the school gardens. Computers and similar technological tools are not used in schools apart from learning purposes. Moreover, children are not allowed to bring their own toys from home.

\section{Data Collection}

In the study, the data were collected using draw-and-tell technique, by drawing a picture and interviewing about the drawing. The application was performed in the activity time of the curriculum; children were seated in a way that they were not affected by each other and told "Draw me a play you want to play". The activity lasted approximately 20-25 minutes. To make sure that children don't feel like testing (Wiseman Roseman, \& Lee, 2018), the questions were asked in line with the prepared interview form while the children were drawing, and their voice was recorded. The studies of Cammisa, Montrone, \& Caroli (2011) and Wiseman, Roseman, \& Lee (2018) were used while compiling the interview questions used in the research. The children were asked the following questions: "What play are you playing? Who are you playing with? What are you doing in the play? Where are you playing?". Each figure in the children's drawings was asked what it represented, and the answers were noted. It was ensured that the children were able to focus and not affected by each other while drawing.

\section{Data Analysis}

The data were analyzed using thematic analysis. Thematic analysis focuses on the discovery and explanation of the themes in the data obtained in qualitative research. Codes representing the themes identified in the thematic analysis process are developed and applied to the raw data (Guest, MacQueen, \& Namey, 2012). Open coding was performed to group the drawings and interview transcripts under the themes and sub-themes. Open Coding involves 
labeling concepts, defining and developing the categories according to their characteristics and dimensions (Khandkar, 2009). While documenting and coding the data obtained in the research, the data collected from children were coded as A, B C and D according to schools. Created themes and sub-themes were separately coded by the researcher and an independent expert, and the encoder reliability among the coders was checked. The reliability of the data analysis was tested using Miles and Huberman's (1994) formula; Agreement Percentage $=[$ Agreement $/$ (Agreement + Disagreement $) X 100]$. Accordingly, the agreement percentage among coders was found to be $96 \%$ for the drawings and $98 \%$ for the interviews.

\section{Results}

This part includes the findings obtained as a result of analyzing children's pictures and the data obtained from interviews.

\section{Themes}

As a result of thematic analysis, five main themes emerged from the drawings and responses of the participants. Themes illustrate the characteristics of the plays that children prefer, and how and where they prefer to play.

Table 1

Participants' Preferred Activity

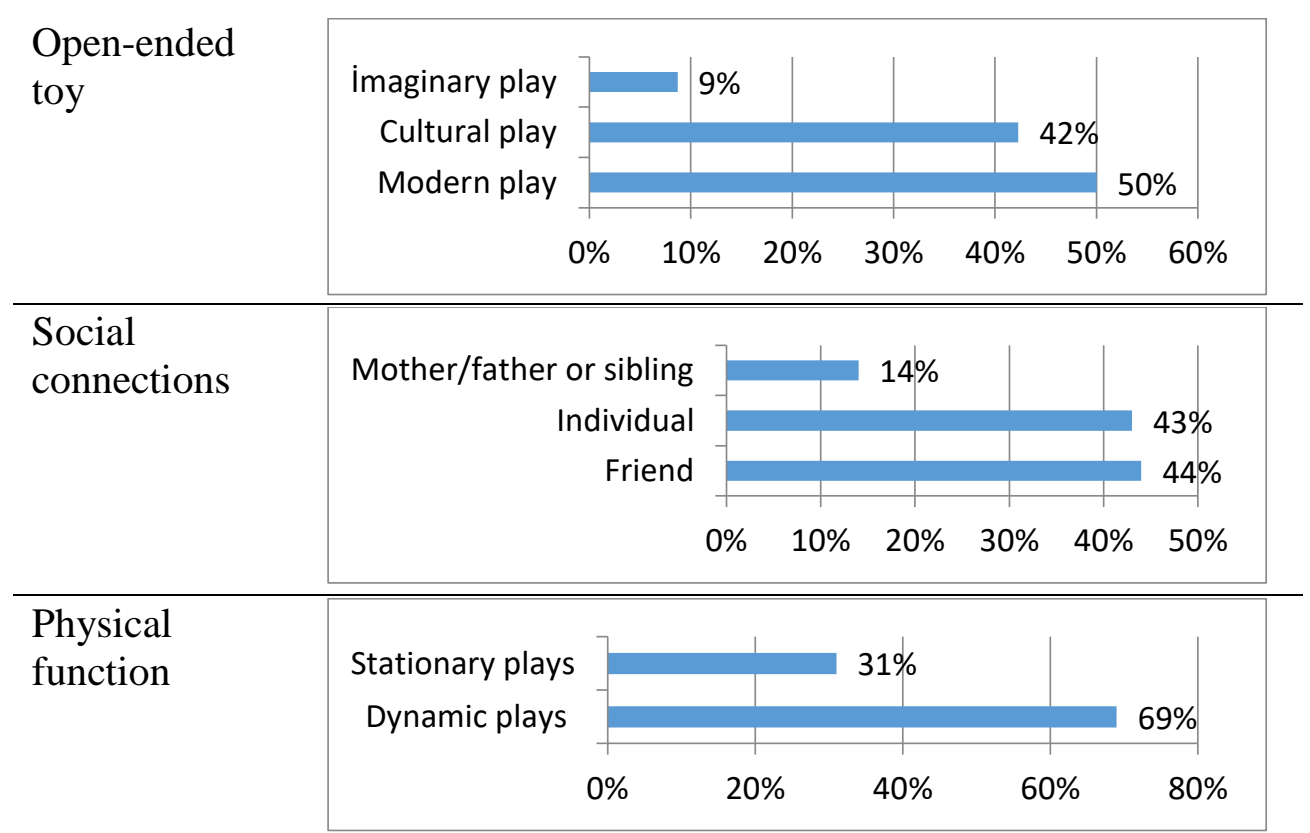




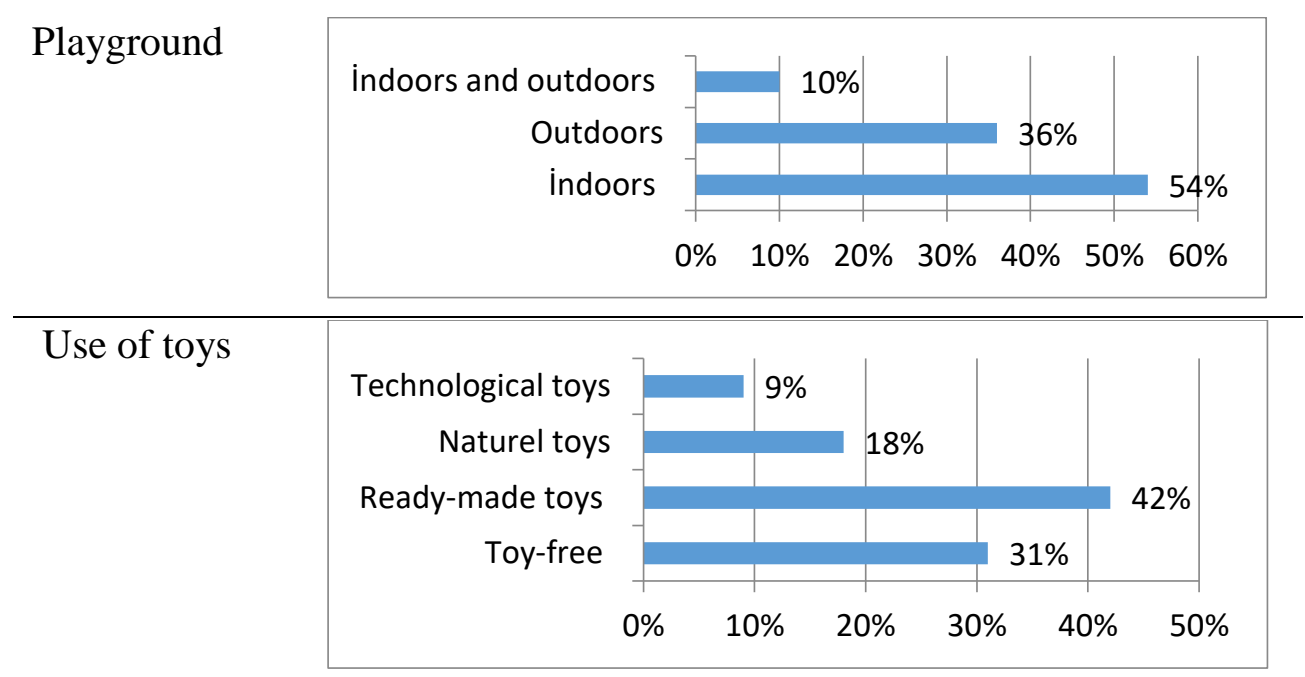

\section{Open-Ended Play}

Children participating in the study preferred the plays played without any adult's direction towards a learning goal. In open-ended plays, which are unstructured, the rules and goals of the play are set by the children and they direct the play according to their own ideas (Sturm, Bekker, Groenendaal, Wesselink, \& Eggen, 2008). It was observed that children love to play the plays that they like and have fun, both in open and close spaces; they are willing to play with friends, family members or just by themselves.

Three different sub-themes of play were identified under open-ended play theme, namely cultural, modern and imaginary plays. The plays that the child manages the playing process without any limitations and that are generally played individually are named as imaginary plays (Bardak, 2018); the plays that spread and develop with contemporary life are called modern plays (Sormaz \& Yüksel, 2012); whereas the plays that come from the past and that carry the values of the community are called cultural plays (Özyürek, Tezel Şahin \& Gündüz, 2018). In the research, $50 \%$ of children drew modern, $42.3 \%$ cultural, and $8.7 \%$ imaginary plays and mentioned in their statements (see Table 1). Children were observed to prefer modern plays such as readymade toys, computers/tablets or football, which are commonly known and played today. Below are examples of some modern plays that children prefer to play. 
Figure 1

Children's Modern Play Preferences

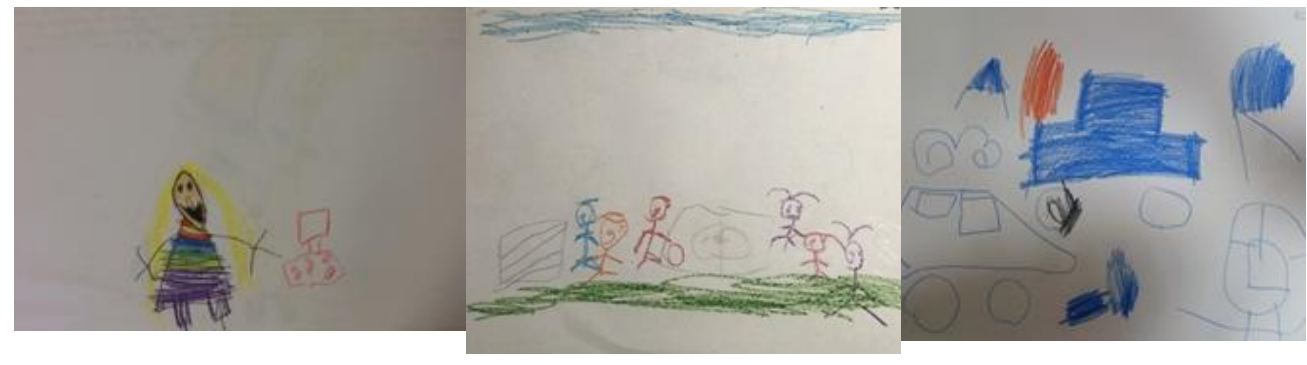

C14: "I'm playing with my computer at home."
B2: "We're playing football with my friends, this is the football ground, these are the players, we are all running after the ball."
A20: "I'm playing with my toys at home."

Regarding cultural plays, which was second most preferred play type, the children expressed 8 different cultural plays such as hopscotch, playing house, blind man's buff. Playing cultural plays that come from past to present and that reflect the characteristics of the community, protects the cultural heritage by transferring it to the next generations (Bay \& Bay, 2019; Girmen, 2012). Below are examples of some cultural plays that children prefer.

Figure 2

Children's Cultural Play Preferences

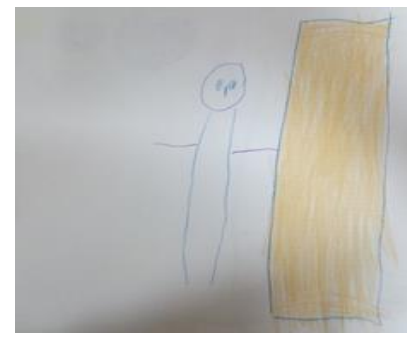

A17: "I'm playing hide and seek. I hid behind the door."

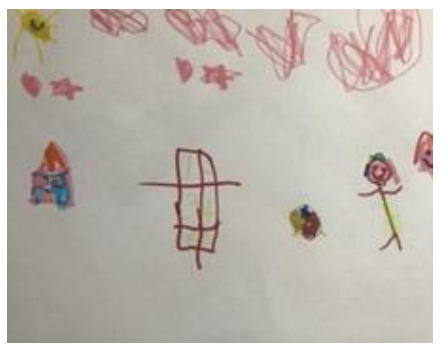

C20: "I love to play hopscotch."

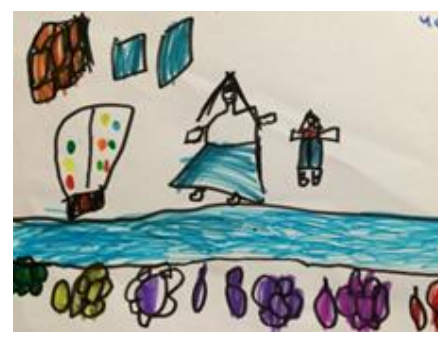

D11: "I'm playing house with my sibling."

In the imaginary plays, children told about the play they created through their pictures. Children can play imaginary plays that they developed by focusing on their own ideas around a topic they choose. These plays, which children can play for days and weeks, can also be seen as a phase of the creative play (Kaçar, 2016). Below are examples of some imaginary plays that children prefer. 
Figure 3

Children's Imaginary Play Preferences
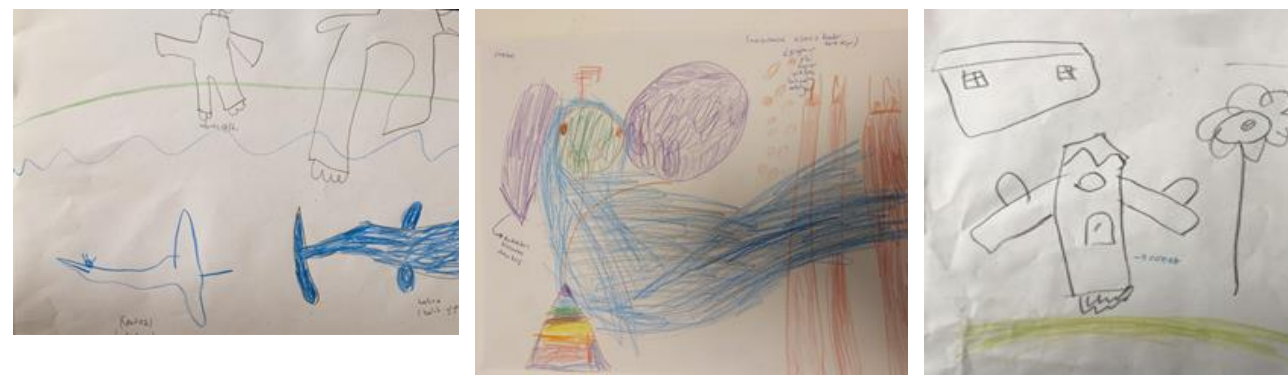

B4: "There is a whale, it eats fish, there is a rough ray here, rough ray swims"
A4: "I drew a huge bird with very big ears; balls, almost as hard as diamonds, are thrown from the high building like rain, frighten away the bird among the towers."
D6: "I'm playing rocketry."

\section{Social Connections:}

The review of the plays preferred by children revealed that $42.5 \%$ of them prefer to play individually, whereas $57.5 \%$ prefer to play together, and social connections theme appeared. While drawing their plays, they also focused on who they are playing with. Children told that they were playing with their friends, parents or siblings. Some children who prefer imaginary plays and some modern plays and who prefer to use toys or technological tools did not draw any people with who they want to play (42.5\%); they did not stated another person when asked "Who are you playing with?". It was found that $43.8 \%$ of the children wanted to play their preferred plays with their friends and $13.7 \%$ of them wanted to play with their parents or siblings. Children were often observed to prefer imaginary plays and the plays involving toys or technological tools (computers, tablets, etc.) individually, which are mostly included in modern plays; whereas other modern plays and cultural plays were preferred to be played together. It was also found that children prefer some plays such as snowballs and hopscotch, which are used to be played together, to be played alone. 
Table 2

Results of Thematic Analysis

Mother/father or A3: I'm playing hide and seek at home with my sister. sibling I hid under the bed.

B17: We are playing in the park with my mom.

C22: We are playing hopscotch with my grandmother in the garden of our house.

C23: I'm playing football with my mom and dad.

C27: We are playing hopscotch with my grandmother, aunt and mom.

D11: We are playing house at home with my sibling.

Friend

B2: We are playing football with my friends; this is the football ground.

B9: We are playing hopscotch in the garden with my friend.

C20: I'm playing hopscotch with my friends in the school garden.

C26: I'm playing football on the ground with my friends.

D2: I'm playing hide and seek with my friends. I hid behind the hut.

D8: I'm playing blind man's buff in the garden with my friends.

Individual

A11: I'm playing on the computer. This is my combat character; I'm getting ready to fight using my soldier.

A15: I'm playing ninja turtle game on the computer.

A22: I'm playing with my animal toys.

B5: The car skips rope and then falls into the mud.

B12: I like to play alone. Here I am building a tower by stacking the cubes.

C17: I'm playing with my dolls and cars.

\section{Physical function}

It was found that the playing styles of the plays preferred by children had different functions physically. Some of the preferred plays under the theme of physical function were observed to be dynamic, while others were still and stationary. Regarding the plays according to their physical function grouped under dynamic and stationary sub-themes, technological games, some modern games played with toys and toy block-type materials and chess $(31 \%)$ were found to be preferred as stationary plays, whereas some modern and 
cultural plays such as football, volleyball, hopscotch, chase that require jumping and running, were preferred as dynamic plays (69\%). The movement element in the plays was observed to be related to the social connections of the children. The plays played individually were mostly stationary, whereas the plays played with friends or family members were dynamic plays.

\section{Playground}

The playground where children want to play has emerged as another characteristic of their preferred plays, which was characterized with indoor, outdoor and indoor or outdoor sub-themes. The plays that children preferred to play close spaces, such as school, classroom and home, are modern plays with toys, technology games played by looking at a screen such as computergames, or some cultural plays such as playing house, hide and seek (54\%). For example: "A1: We're playing house with my mother at home. A12: I'm playing with my concrete truck at home. C3: I'm playing with the tablet in my house. C10: I'm driving my car in the classroom". The plays, that children preferred to play in open spaces, such as garden, park, playground, included the plays such as football, basketball, hopscotch, chase (36\%). For example: "D3: I'm playing hide and seek with my friends outside. D7: We're playing chase in the garden. C24: We are playing football with my father. This is the garden of our house". Children stated that they can play imaginary plays and remote-control car plays both indoors and outdoors (10\%). For example: "A4: I can play with my bird everywhere. B11: For example, the balloon turns red when it bounces, there is a movement for each color. I can play with my balloon everywhere. C6: I can play anywhere with my remote-control car."

\section{Use of Toys}

It was observed that some materials are used in the plays preferred by children and they included toys in the drawing and explanation of the plays. The play materials classified under Use of Toys theme were grouped under ready-made, natural, technological and toy-free sub-themes. Since play materials are not used in imaginary plays and in some cultural plays, such as and hide and seek, these plays were classified as toy-free $(31 \%)$; stone and snow used in hopscotch and snowball plays were natural materials (18\%), computer and tablet were technological tools (9\%), and materials such as cars, toy-block, dolls were ready-made toys (42\%).

\section{Discussion}

In this study, draw-and-tell technique and drawings were used to understand the play preferences of children and the characteristics of their preferred plays in Turkey. The children participating in the research showed a desire to play modern, cultural or imaginary open-ended plays with varying 
social connection, physical function, playground and toy preference. These themes were discussed over the relevant literature to identify the implications for preschool educators.

\section{Children's Play Preferences Open-Ended Plays}

The daily flow of pre-school curriculum implemented in Turkey includes unstructured "play time" activity. During this period, children play freely in their preferred centers, garden or open spaces (MoNE, 2013). In the current study, children defined play as unstructured, open-ended plays which are at their discretion, and which are not within the scope of a teaching objective. The open-ended play time activity included in the curriculum might have an impact upon children's play preferences. Similar results were obtained in previous studies (Noonan, Boddy, Fairclough, \& Knowles, 2016; Wiseman et al., 2018; Tuğrul et al., 2019).

Even though some children stated the participation of family members in their plays, it was observed that children wanted to play autonomously. The involvement or intervention of adults creates pressure on the child's play and restricts them from acting comfortably (Howard \& Mclnnes, 2013). However, it should not be considered that children's plays should be completely free of adult guidance. Many studies have been carried out about how teachers can participate in unstructured open-ended plays (Özgünlü \& Çelik, 2018; Singer, Nederend, Penninx, Tajik, \& Boom, 2013; Tarman \& Tarman, 2011; Yang, 2013). The fact that the teacher provides the child with the opportunity to choose and makes the child use his/her own preferences, allows the child to perceive the activity as a play and focus on it; and allows him/her to feel more competent without thinking about the risk of failure and to be more involved with the activity (King \& Howard, 2016). During the activity, teachers can take the role of preparing the environment, observer, playmate or supporter in case of problems (Özgünlü \& Çelik, 2018; Singer et al., 2013; Tarman \& Tarman, 2011; Yang, 2013).

The current study revealed that children play modern, cultural and imaginary open-ended plays. Among these plays, mostly modern plays, where ready-made toys and technological devices are frequently used, were preferred. In the study conducted by Sapsağlam (2018) in Turkey about fiveyear-old children's play preferences among the offered plays, most preferred plays were the ones involving technological devices. In the study of Özdemir and Ramazan (2014), in which children's play preferences have been identified based on teacher perspectives, it was found that girls mostly preferred playing house, which is a cultural play, whereas boys preferred to play modern plays with ready-made toys. Today, technological developments and the increase in 
urbanization have an impact on children's play preferences as well (Bento \& Dias, 2017).

\section{Social Connections}

In the current research, the majority of children expressed their friends and family members, who have an important role in social development, as playmates in their plays. Similarly, in their study examining preschool children's play behavior in Turkey and United States, Duman and Temel (2011) concluded that children mostly play social plays with their peers. In the study examining the play types that children prefer in the classroom, Kaçar (2016) observed that children mostly preferred peer-plays, which are also referred as group plays. Howard et al. (2006) conducted a study with 92 preschool children, about how children classify play and learning according to social context, and they reached the conclusion that the absence of the teacher is associated with the play and that the child makes a connection between the peers and the play. In the current study, children stated that they prefer to play open-ended plays through social connections, which can be considered as an effect of the absence of teacher.

In addition, in preschool period children tend to choose their playmates according to gender (Golombok, Rust, Golding, Zervoulis, Croudace, Hines, 2008). Taş (2018) have examined children's play preferences in terms of gender by observing preschool children in their free play time and by interviewing teachers and have found that children prefer to play with their friends of the same sex. The current study showed that children who stated to play with their friends, also indicated the gender of their playmates as: "I'm playing chase with my friend ......." The fact that children stated to play with either their friends or family members, can contribute to the positive disposition that the children have towards social play in open-ended plays.

\section{Physical Function}

In the research, it was observed that children mostly prefer plays that require them to move physically, either with or without a toy. Dynamic plays strengthen children's muscles and improve their body coordination (Kaçar, 2016). In an experimental study where Ogelman, Gündoğan, Sarıkaya and Önder (2016) investigated the effect of unstructured and dynamic play practices on five-year-old children's peer relationships, they concluded that social behavior levels of the children playing unstructured and dynamic plays increases, whereas their peer violence exposure and physical aggression levels decrease. In this context, the children's high preference of dynamic plays in the current study should be interpreted positively.

In the study of Barbosa and Oliveira (2016) where they reviewed seven studies, they found that the plays initiated by children involve more physical 
activity, whereas the plays initiated by the adults have low physical activity. Regarding the results of this study, open-ended unstructured plays that do not involve teacher intervention are thought to direct children to the plays that allow them to move more.

\section{Playground}

Outdoor plays allow children to observe their surroundings and move their bodies in a coordinated manner (Morrison, 2007). In addition, dynamic plays that are played in open spaces are effective in strengthening social ties between children and reducing negative behaviors (Ogelman et al., 2016). In the experimental study of Yildirim and Akamca (2017), where they implemented outdoor activities for preschool children, they observed improvements in children's cognitive, social-emotional, linguistic and motor skills. Outdoor plays contribute to children's physical development and enhance their immunity by ensuring that they receive sunlight and natural elements in nature, they also increase their attention levels and makes them feel better (Bento \& Dias, 2017). Despite many benefits of outdoor plays, which are mentioned in the literature, the current research discovered that the plays preferred by children were mostly indoor plays. Similarly, Clements (2004), in his research examining children's playing behavior in open spaces, concluded that very little time was spent on outdoor plays due to the impact of television and digital media addiction on children.

Children's play preferences may vary according to different factors. However, today, children's unstructured outdoor activities seem to decrease day by day (Bento \& Dias, 2017; Kemple, Kenney, \& Smith-Bonahue, 2016). Research emphasizes the importance of natural environments that allow children to discover and that support their creativity and collaboration (Tuğrul et al., 2019; Zamani, 2016). Given the positive impact of outdoor plays on children's development, teachers are recommended to provide children with play opportunities in natural settings (Bento \& Dias, 2017; Kemple et al., 2016; Miranda et al., 2017). In this context, placing more outdoor play materials and natural materials such as water and sand that children can use, will allow children to prefer outdoor plays more and participate in them (Miranda et al., 2017; Wiseman et al., 2018; Zamani, 2016)

\section{Use of Toys:}

The study revealed that children prefer plays that they use ready-made toys, as well as their preferences for the plays without toys. While the parents were observed to make their own toys in the past (Holmes, 2012), today's children mostly prefer ready-made toys such as cars and babies. Previous studies also support the results of the current study (Holmes, 2012; Özdemir, 2014; Tuğrul, Ertürk, Özen Altinkaynak, \& Güneş, 2014). 
Ready-made toys are defined as materials sold for children to play (Nelson, 2005). However, playing with natural materials such as sand, stone and water enables children to know the nature and develops their creativity (Kaçar, 2016). In the study where Tuğrul et al. (2019) examined preschool children's play opportunities at school, based on the opinions of 460 teachers, they reported that children mostly prefer to play with natural materials in open spaces. Although some studies have attempted to determine the differentiation of toy preferences according to children's gender (Martin, Eisenbud, \& Rose, 1995; Nelson, 2005; Spinner, Cameron, \& Calogero, 2018; Todd, Fischer, Di Costa, Roestorf, Harbor, Hardiman, \& Barry, 2018), natural materials such as water, soil, stone present in open spaces attract the attention of all children and provide them with many play options (Bento \& Dias, 2017). In this context, unstructured and manipulable natural environments including trees, flowers and shrubs should be formed in educational environments, which would allow children to play the play they want with the toy they want (Fjortoft \& Sageie 2000; Malone \& Tranter, 2003; Geney, Özsoy, \& Bay, 2019). The results of the current research highlight the need to use natural materials as toys for children. Teachers are advised to understand the contexts that shape children's play and toy preferences

\section{Draw-and-Tell Technique}

The draw-and-tell technique is a method for conducting interviews and facilitating the interpretation by focusing the plays that children preferred in their drawings; it was used to understand children's play preferences and the characteristics of their preferred plays. Drawings gives a meaning to the noticeable and unnoticeable characteristics of children's social environments and plays through shapes (Engel, 1995). In addition, drawings allow the child's experiences to be arranged before sharing (Gross \& Hayne, 1998). What children say about their drawings reveals their feelings embedded in their drawings (Hanney \& Kozlowska, 2002). In this way, children can talk more easily about the events that they cannot define (Gross \& Hayne, 1998; Wesson \& Salmon, 2001). The draw-and-tell technique is considered as a childcentered method that reduce social demand potential of the researcher on the child during interview (Gross \& Hayne, 1998). Therefore, allowing children to draw before conducting an interview is a very effective strategy (Driessnack, 2005). As the drawings are easier to interpret, the drawings of five-year-old children were evaluated in the study. It is recommended position children in a large table, at a distance to prevent them from affecting the others and cheating (Wiseman et al, 2018). 


\section{Limitations of the Study and Direction for Future Research}

This study, conducted in the kindergartens in Turkey, has expanded the scope of the research on children's play preferences in which draw-and-tell technique was employed. However, there are some limitations. Data were collected from 80 participants in 4 schools with medium socio-economic level, in a province of Turkey. It should be considered that the play preferences of children may change with demographic characteristics of the participants or with cultural differences. Considering that the schools in which the participants were recruited have similar educational environments, the themes obtained in the study may not reflect the diversity of children's perspectives.

In addition, since the study is the first research addressing play preferences of preschool children using draw-and-tell technique in Turkey, the results of the study should be supported and confirmed by other researches.

For future research in Turkey, it is very important to work on larger samples. It is recommended for researchers to obtain a holistic picture by including the variety, wealth, diversity and contradictions that may be in the universe. In this context, according to the maximum diversity in qualitative research sample (Yıldırım and Şimşek, 2013) children with different socioeconomic levels in different regions/provinces of Turkey can be identified as the study group by researchers. The play preferences of children can be generalized by taking larger samples through quantitative research. The factors affecting children play preferences and the impacts of these plays on them should be investigated. The plays that children choose to play and the relationships between the play and the child can be examined using observation-based sequential analysis.

\section{Conclusion}

Pre-school children's play preferences and the characteristics of these plays provide educators with important information. The findings will help to support children's participation in entertaining and creative activities in natural settings (Wiseman et al., 2018). Children prefer open-ended plays, which shows their desire for unconfigured plays. Children often prefer dynamic plays played together (family/friends), which will allow the development of play activities in this direction. In addition, in order to ensure that choosing indoor plays played with ready-made toys doesn't pose a risk for children, the need to organize play activities in line with contemporary research results was revealed. 


\section{References:}

1. Akçay, D., \& Özcebe, H. (2012). Okul öncesi eğitim alan çocukların ve ailelerinin bilgisayar oyunu oynama alışkanlıklarının değerlendirilmesi. Çocuk Dergisi, 12(2), 66-71.

2. Aksoy, P., \& Baran, G. (2017). Annelerin cinsiyet rollerine ilişkin özellikleri ile çocukların oyuncak tercihleri ve oynadıkları oyun türleri arasındaki ilişki üzerine bir çalışma. Eğitimde Nitel Araştırmalar Dergisi, 5(1), 102-136.

3. Alabay, E., \& Güder, S. Y. (2018). Changing face of plays: A comparative research of childhood plays of older adults and plays of today's. Bartın Üniversitesi Eğitim Fakültesi Dergisi, 7(1), 237-259.

4. Angell, C., Alexander, J., \& Hunt, J. A. (2015). 'Draw, write and tell': A literature review and methodological development on the draw and write research method. Journal of Early Childhood Research, 13(1), $17-28$.

5. Arabacı, N., \& Çıtak, Ş. (2017). Okul öncesi dönemdeki çocukların " oyun" ve "“açık alan (bahçe)" etkinlikleri ile ilgili görüşlerinin incelenmesi ve örnek bir bahçe düzenleme çalışması. Mediterranean Journal of Educational Research, 11(21), 28-43.

6. Aslan, F. (2010). Okul öncesi eğitim kurumlarında dış mekan tasarımında çocukların beklentilerinin belirlenmesi [Unpublished master's thesis]. Ankara Üniversitesi, Ankara.

7. Ashiabi, G. S. (2007). Play in the preschool classroom: Its socioemotional significance and the teacher's role in play. Early Childhood Education Journal, 35, 199-207. doi:10.1007/s10643-0070165-8

8. Barbosa, H. C., \& de Oliveira, A. R. (2016). Physical activity of preschool children: A review. Journal of Physiotherapy and Physical Rehabilitation, 1(2), 1-5. doi:10.4172/2573-0312.1000111

9. Bardak, M. (2018). Oyun temelli öğrenme. In A. Gürol (Eds.), Erken çocukluk döneminde öğrenme yaklaşımları (pp. 207-230). İstanbul: Efe Akademi.

10. Bay, D. N., \& Bay, Y. (2019). Balkanlardaki çocuk oyunları. Sınırsız Eğitim ve Araştırma Dergisi, 4(2), 200-223.

11. Bento, G., \& Dias, G. (2017). The importance of outdoor play for young children's healthy development. Porto Biomedical Journal, 2(5), 157-160.

12. Bredekamp, S. (2015). Erken çocukluk eğitiminde etkili uygulamalar. (Effective practices in early childhood education, 2nd Edition). (Hatice Zeynep İnan \& Taşkın İnan, Trans.). 343-345. Ankara: Nobel.

13. Cammisa, M, Montrone, R, \& Caroli, M (2011) Development and results of a new methodology to perform focus group with preschool 
children on their beliefs and attitudes on physical activity. International Journal of Pediatric Obesity 6(2), 22-27.

14. Clements, R. (2004). An investigation of the status of outdoor play. Contemporary issues in early childhood, 5(1), 68-80.

15. Coplan, R. J., Rubin, K. H., \& Findlay, L. C. (2006). Social and nonsocial play. In D. P. Fromberg \& D. Bergen (Eds.), Play from birth to twelve: Contexts, perspectives, and meanings (pp. 75-86). New York, NY: Garland Press

16. Driessnack, M. (2005). Children's drawings as facilitators of communication: A meta-analysis. Journal of Pediatric Nursing, 20(6), 415-423.

17. Duman, G., \& Temel, Z. F. (2011). Türkiye ve Amerika Birleşik Devletleri'nde anasınıfına devam eden çocukların oyun davranışlarının incelenmesi. Kırıkkale Üniversitesi Sosyal Bilimler Dergisi, 1(1), 279298.

18. Emslie, A., \& Mesle, C. R. (2009). Play: The use of play in early childhood education. Gyanodaya, 2(2), 1-26.

19. Engel, B. S. (1995). Considering children's art: Why and how to value their works. Washington, DC: National Association for the Education of Young Children.

20. Erbay, F., \& Durmuşoğlu Saltalı, N. (2012). Altı yaş çocuklarının günlük yaşantılarında oyunun yeri ve annelerin oyun alg1sı. Ahi Evran Üniversitesi Kırşehir Eğitim Fakültesi Dergisi (KEFAD), 13(2), 249264.

21. Ertuğrul, B. (2019). Türkiye'de 1990-2019 yılları arasında uygulanan okul öncesi eğitim politikalarının değerlendirilmesi [Unpublished master's thesis]. Hacettepe University, Ankara.

22. Fırat, H. (2013). Çocuk oyunları-eğitim ilişkisi: Bezirgan başı örneği. Electronic Turkish Studies, 8(13), 885-896.

23. Fisher, K., Hirsh-Pasek, K., Golinkoff, R. M., Singer, D. G., \& Berk, L. (2011). Playing around in school: Implications for learning and educational policy. In A. D. Pellegrini (Ed.), The Oxford handbook of the development of play (pp. 341-362). New York, NY: Oxford University Press.

24. Fjortoft, I., \& Sageie, J. (2000). The Natural environment as a playground for children: Landscape description and analyses of a natural landscape. Landscape and Urban Planning 48(1/2), 83-97.

25. Geney, F., Özsoy, Z., \& Bay, D. N. (2019). Okul Öncesi Eğitim Kurumlarının Dış Mekan Özellikleri: Eskişehir İli Örneği. Eskişehir Osmangazi Üniversitesi Sosyal Bilimler Dergisi, 20, 735-767. 
26. Girmen, P. (2012). Eskişehir folklorunda çocuk oyunları ve bu oyunların yaşam becerisi kazandırmadaki rolü. Millî Folklor, 24(95), 263-273.

27. Gialamas, A., Mittinty, M. N., Sawyer, M. G., Zubrick, S. R., \& Lynch, J. (2014). Child care quality and children's cognitive and socioemotional development: An Australian longitudinal study. Early Child Development and Care, 184, 1-21. doi:10.1080/03004430.2013.847835

28. Golombok, S., Rust, J., Golding, K., Zervoulis, T., Croudace, J., \& Hines, M. (2008). Developmental trajectories of sex-typed behavior in boys and girls: A longitudinal general population study of children aged 2.5-8 years. Child Development, 79(5), 1583-1593. doi: 10.1111/j.1467-8624.2008.01207.

29. Göncü, A., \& Weber, E. (2000). Preschoolers' classroom activities and interactions with peers and teachers. Early Education and Development, 11(1), 93-107.

30. Gross, J., \& Hayne, H. (1998). Drawing facilitates children's verbal reports of emotionally laden events. Journal of Experimental Psychology: Applied, 4(2), 163-179.

31. Guest, G., MacQueen, K. M., \& Namey, E. E. (2012). Introduction to applied thematic analysis. Thousand Oaks, CA: SAGE.

32. Gündoğdu, Z., Seytepe, Ö., Pelit, B. M., Doğru, H., Güner, B., Arıkı, E., Akçomak, Z., Kale, B., Moran, İ., Aydoğdu, G., \& Kaya, E. (2016). Okul öncesi çocuklarda medya kullanımı. Kocaeli Üniversitesi Sağlık Bilimleri Dergisi, 2(2), 6-10.

33. Han, M., Moore, N., Vukelich, C., \& Buell, M. (2010). Does play make a difference? Effects of play intervention on at-risk preschoolers' vocabulary learning. American Journal of Play, 3, 82-105.

34. Hanney, L., \& Kozlowska, K. (2002). Healing traumatized children: Creating illustrated storybooks in family therapy. Family Process, 41(1), 37-65.

35. Holmes, R. (2012). Children's play preferences in the Pacific Rim: Then and now. Play: A polyphony of research, theories and issues, 12, 27-66.

36. Horstman, M., Aldiss, S., Richardson, A., \& Gibson, F. (2008). Methodological issues when using the draw and write technique with children aged 6 to 12 years. Qualitative health research, 18(7), 10011011.

37. Howard, J., \& McInnes, K. (2013). The impact of children's perception of an activity as play rather than not play on emotional well-being. Child: care, health and development, 39(5), 737-742. 
38. Howard, J., Jenvey, V., \& Hill, C. (2006). Children's categorisation of play and learning based on social context. Early Child Development and Care, 176(3-4), 379-393.

39. Howes, C. (2011). Social play of children with adults and peers. In A. D. Pellegrini (Ed.), The Oxford handbook of the development of play (pp. 231-244). New York, NY: Oxford University Press.

40. Kaçar, S. (2016).Okul öncesi normal gelişim gösteren 5-6 yaş grubu çocukların tercih ettikleri oyun türlerinin dil gelişimi ve problem çözme becerisi üzerine etkisinin incelenmesi [Unpublished master's thesis]. Maltepe Üniversitesi, İstanbul.

41. Kemple, K. M., Oh, J., Kenney, E., \& Smith-Bonahue, T. (2016). The power of outdoor play and play in natural environments. Childhood education, 92(6), 446-454.

42. Khandkar, S. H. (2009). Open coding. Retrieved from http://pages.cpsc.ucalgary.ca/ saul/wiki/uploads/CPSC681/opencoding.pdf (Accessed 13 February 2020).

43. King, P., \& Howard, J. (2016). Free choice or adaptable choice: SelfDetermination theory and play. American Journal of Play, 9(1), 56-70.

44. Koçyiğit, S., \& Baydilek, N. (2015). Okul öncesi dönem çocuklarının oyun algılarının incelenmesi. Yüzüncü Yll Üniversitesi Ĕgitim Fakültesi Dergisi, 7(1), s.1-28.

45. Koçyiğit,S. , Tuğluk, M.N., \& Kök, M. (2007) Çocuğun gelişim sürecinde eğitsel bir etkinlik olarak oyun. Kazım Karabekir Eğitim Fakültesi Dergisi, 16, 324-342.

46. Malone, K., \& Tranter, P. (2003). Children's environmental learning and the use, design and management of schoolgrounds. Children Youth and Environments, 13(2), 87-137.

47. Mangır, M., \& Aktaş, Y. (1993). Çocuğun gelişiminde oyunun önemi. Yaşadıkça Eğitim Dergisi, 26(16), 14-19.

48. Martin, C. L., Eisenbud, L., \& Rose, H. (1995). Children's genderbased reasoning about toys. Child Development, 66, 1453-1471.

49. Miles, M. B., \& Huberman, A. M. (1994). Qualitative data analysis: An expanded sourcebook. California: Sage.

50. Milli Ĕ̆itim Bakanlığı (MEB). (2018). 2023 ĕgitim vizyonu. Milli Eğitim Bakanlığgl. http://2023vizyonu.meb.gov.tr/doc/2023_EGITIM_VIZYONU.pdf (Accessed 04 February 2020)

51. Milli Eğitim Bakanlığı (MEB). (2013). Okul öncesi ĕgitimi programı [Early childhood education curriculum]. Ankara, Turkey: MEB.

52. Miranda, N., Larrea, I., Muela, A., \& Barandiaran, A. (2017). Preschool children's social play and involvement in the outdoor environment. Early Education and Development, 28(5), 525-540. 
53. Morrison, G. S. (2007). Early childhood education today (8th edition). Upper Saddle River, NJ: Merrill Prentice Hall.

54. Morrow, V., \& Richards, M. (1996) Çocuklarla sosyal araştırma etiği: Genel bir bakış. Cocuklar ve toplum 10, 90-105.

55. Nelson, A. (2005). Children's toy collections in Sweden-A less gender-typed country? Sex roles, 52(1-2), 93-102.

56. Nicholson, J., Kurnik, J., Jevgjovikj, M., \& Ufoegbune, V. (2015). Deconstructing adults' and children's discourse on children's play: Listening to children's voices to destabilise deficit narratives. Early Child Development and Care, 185, 1569-1586.

57. Noonan, R. J., Boddy, L. M., Fairclough, S. J., \& Knowles, Z. R. (2016). Write, draw, show, and tell: a child-centred dual methodology to explore perceptions of out-of-school physical activity. BMC public health, 16(1), 326.

58. Ogelman, H. G., Gündoğan, A., Sarıkaya, H. E., \& Önder, A. (2016). Anaokuluna devam eden çocuklarda serbest ve hareketli oyun düzenlemelerinin akran ilişkilerine etkisinin incelenmesi. Fırat Üniversitesi Sosyal Bilimler Dergisi, 26(2), 163-174.

59. Özdemir, S. (2014). 5-6 Yas grubu çocuklarin serbest zaman etkinliklerindeki oyun ve oyuncak tercihlerinin incelenmesi. Journal of Educational Science, 2(2), 1-15.

60. Özdemir, A., \& Ramazan, O. (2014). Okul öncesi öğretmenlerinin oyuna ilişkin görüşleri. Eğitim ve Öğretim Araştırmaları Dergisi, 3(4), 298-308.

61. Özdenk, Ç. ( 2007). 6 Yaş grubu ögrencilerinin psikomotor gelisimlerinin sağlanmasında oyunun yeri ve önemi [Unpublished master's thesis]. Firat Üniversitesi, Elazı̆̆.

62. Özgünlü, M., \& Çelik, M. (2018). Okul öncesi eğitimde yapılandırılmamış oyuna ilişkin öğretmen görüşlerinin incelenmesi. Kastamonu Education Journal, 26(5), 1691-1700.

63. Özyürek, A., Şahin, F. T., \& Gündüz, Z. B. (2018). Nesilden Nesile Kültürel Aktarımda Oyun ve Oyuncakların Rolü. Çukurova Üniversitesi Sosyal Bilimler Enstitüsü Dergisi, 27(1), 1-12.

64. Parten, M. B. (1932). Social participation among pre-school children. Journal of Abnormal and Social Psychology, 27, 243-269. doi: $10.1037 / \mathrm{h} 0074524$

65. Patton, M. Q. (2014). Nitel araştırma ve değerlendirme yöntemleri. (M. Bütün \& S. B. Demir, Trans.). Ankara: Pegem.

66. Pellegrini, A. D. (2011). The Oxford handbook of the development of play. New York, NY: Oxford University Press. 
67. Pellegrini, A.D., \& Smith, P. K. (1998). The development of play during childhood: forms and possible functions. Journal of Child Psychology \& Psychiatry Review, 3, 51- 57.

68. Piaget, J. (1962). Play, dreams and imitation in childhood. New York: Norton.

69. Pinto, A. I., Pessanha, M., \& Aguiar, C. (2013). Effects of home environment and center-based child care quality on children's language, communication, and literacy outcomes. Early Childhood Research Quarterly, 28, 94-101. doi:10.1016/j.ecresq.2012.07.001

70. Robson, S. (1993). "Best of all I like Choosing Time" Talking with children about play and work. Early Child Development and Care, 92(1), 37-51.

71. Saracho, O. N. (2012). An integrated play-based curriculum for young children. New York: Routledge.

72. Santer, J., Griffiths, C., \& Goodall, D. (2007). Free play in early childhood: A literature review. London: National Children's Bureau.

73. Sapsağlam, Ö. (2018). Okul öncesi dönem çocuklarının değişen oyun tercihleri. Ahi Evran Üniversitesi Kırşehir Eğitim Fakültesi Dergisi, 19(1), 1122-1235.

74. Singer, E., Nederend, M., Penninx, L., Tajik, M., \& Boom, J. (2013). Teacher's role in supporting young children's level of play engagement. Early Child Development and Care, 184(8), 1233-1249.

75. Smith, P. K., \& Hart, C. H. (Eds.). (2004). The Wiley-Blackwell handbook of childhood social development. Malden, MA: Wiley.

76. Sormaz, F., \& Yüksel, H. (2012). Değişen çocukluk, oyun ve oyuncağın endüstrileşmesi ve tüketim kültürü. Gaziantep Üniversitesi Sosyal Bilimler Dergisi, 11(3): 985 -1008.

77. Spinner, L., Cameron, L., \& Calogero, R. (2018). Peer toy play as a gateway to children's gender flexibility: The effect of (counter) stereotypic portrayals of peers in children's magazines. Sex roles, 79(5-6), 314-328.

78. Sturm, J., Bekker, T., Groenendaal, B., Wesselink, R., \& Eggen, B. (2008). Key issues for the successful design of an intelligent interactive playground. Proceedings of the 7th International Conference on Interaction Design and Children, Chicago, Illinois, pp.258-265.

79. Sun, M., \& Seyrek, H. (1997). Okulöncesi Eğitimde Oyun. İzmir: Müzik Eserleri Yayınları.

80. Tarman, B., \& Tarman, İ. (2011). Teachers' involvement in children's play and social interaction. Elemantary Education Online, 1(10), 325337. 
81. Tas, I. (2018). An Analysis on Play and Playmate Preferences of 48 to 66 Months Old Children in the Context of Gender. Educational Research and Reviews, 13(13), 511-517.

82. Taylor, M. E., \& Boyer, W. (2020). Play-based learning: Evidencebased research to improve children's learning experiences in the kindergarten classroom. Early Childhood Education Journal, 48(2), 127-133.

83. Theobald, M., Danby, S., Einarsdóttir, J., Bourne, J., Jones, D., Ross, S., Knaggs, H., \& Carter-Jones, C.(2015). Children's perspectives of play and learning for educational practice. Education Sciences, 5, 345362.

84. Todd, B. K., Fischer, R. A., Di Costa, S., Roestorf, A., Harbour, K., Hardiman, P., \& Barry, J. A. (2018). Sex differences in children's toy preferences: A systematic review, meta-regression, and meta-analysis. Infant and Child Development, 27(2), 1-29.

85. Tuğrul, B., Aslan, Ö. M., Ertürk, G., \& Altınkaynak, Ş. (2014). Anaokuluna devam eden altı yaşındaki çocuklar ile okul öncesi öğretmenlerinin oyun hakkındaki görüşlerinin incelenmesi. Inönü Üniversitesi Eğitim Fakültesi Dergisi 15(1), 97-116.

86. Tuğrul, B., Ertürk, H. G., Altınkaynak, Ö. Ş., \& Güneş, G. (2014). Oyunun üç kuşaktaki değişimi. The Journal of Academic Social Science Studies, 27, 1-16.

87. Tuğrul, B., Boz, M., Uludağ, G., Aslan, Ö. M., Çelik, S. S., \& Çapan, A. S. (2019). Okul öncesi dönemdeki çocukların okuldaki oyun olanaklarının incelenmesi. Trakya Eğitim Dergisi, 9(2), 185-198.

88. Türkmenoğlu, F. (2005). 60-72 Aylık çocukların matematik becerilerini kazanmalarında, oyun yoluyla matematik becerilerini kazandırma programının etkisinin incelenmesi [Unpublished master's thesis]. Gazi Üniversitesi, Ankara.

89. Ulutaş, A. (2011). Okul öncesi dönemde drama ve oyunun önemi. Adıyaman Üniversitesi Sosyal Bilimler Enstitüsü Dergisi, 4(6), 233242.

90. Uygun, N., \& Kozikoğlu, İ. (2019). Okul öncesi eğitim kurumlarına devam eden çocukların oyun davranışlarının incelenmesi. Anadolu Üniversitesi Ĕ̌itim Bilimleri Enstitüsü Dergisi, 9(2), 787-817.

91. Vygotsky, L.S. (1978). Mind in society: The development of higher psychological processes. Cambridge, MA: Harvard University Press.

92. Waite, S. (2010). Losing our way? The downward path for outdoor learning for children aged 2-11 years. Journal of Adventure Education \& Outdoor Learning, 10(2), 111-126. doi:10.1080/14729679.2010.531087 
93. Weisberg, D. S., Zosh, J. M., Hirsh-Pasek, K., \& Golinkoff, R. M. (2013). Talking it up: Play, language development, and the role of adult support. American Journal of Play, 6, 39-54.

94. Wesson, M., \& Salmon, K. (2001). Drawing and showing: Helping children to report emotionally laden events. Applied Cognitive Psychology, 15, 301-320.

95. Wilcox-Herzog, A. \& Kontos, S. (1998) The nature of teacher talk in early childhood classrooms and its relationship to children's play with objects and peers. Journal of Genetic Psychology, 159(1), 30-44.

96. Wiseman, N., Rossmann, C., Lee, J., \& Harris, N. (2018). "It's like you are in the jungle": Using the draw-and-tell method to explore preschool children's play preferences and factors that shape their active play. Health Promotion Journal of Australia, 30, 85-94.

97. Wong, S. M., Wang, Z., \& Cheng, D. (2011). A Play-based curriculum: Hong Kong children's perception of play and nonplay. International Journal of Learning, 17(10), 165-180.

98. Wortham, C. S. (2006), Early childhood curriculum, developmental bases for learning and teaching (4th edition). New Jersey: Pearson/ Merrill/Prentice Hall.

99. Yang, Y. (2013). A qualitative study of teachers' involvement in children's play. Literacy Information and Computer Education Journal, 4(4), 1244-1251

100. Yavuzer, H. (2000). Eğitim ve gelişim özellikleriyle okul çağı çocuğu (5. Basım). İstanbul: Remzi Kitabevi.

101. Yıldırım, G., \& Akamca, G. Ö. (2017). The effect of outdoor learning activities on the development of preschool children. South African Journal of Education, 37(2), 1-10.

102. Yıldırım, A., Şimşek, H. (2013). Sosyal bilimlerde nitel araştırma yöntemleri. Ankara: Seçkin.

103.Zamani, Z. (2016). The woods is a more free space for children to be creative; their imagination kind of sparks out there: Exploring young children's cognitive play opportunities in natural, manufactured and mixed outdoor preschool zones. Journal of adventure education and outdoor learning, 16(2), 172-189. 